$22 \mathrm{CT}$ 最低出力条件の検討一上腹部スクリーニングスキャンー 竹田医師会病院 江藤芳浩

【目的】ヘリカルC丁のスクリーニングスキャンにおいて，診断に適 する最低出力条件を模索する。

【方法】東芝X-vision/GXを使用する。条件は管電圧120kVと $130 \mathrm{kV}$ ，管電流は100～300mAをそれぞれ組み合わせる．各条件 でファントムと、3 体型のボランティアをスキャンし評価する．ま た20秒連続スキャンの熱量上昇率を比較検討する。

【結果】120kVと130kVを比較した場合，画質，管球負荷、被曝の点 から、120kVより130kVの方がメリットが高かった，今回の装置で は，大柄体型では130kV/200mA，標準以下体型で130kV/150mA であった。

\section{3 低コントラスト領域におけるへリカルCTの応用について} 白石共立病院 北村茂利，他１名

低コントラスト領域について撮影条件を变化させ，画像描出能を 測定し、ヘリカルCTの応用について検討した。結果はテーブル速 度を遅くするほど良かった。これはスライス形状が影響していると 考えられる。また，ビーム幅においての変化は少なかった。これは C丁值差が少ないためにパーシャルボリューム効果とノイズの影響 で変化は少なかったと考えられる.さらに，mAs值を上げること により描出は良くなったが、被曝を考慮する必要がある。これらす べてにおいてCT值差が大きいほど，そして，従来法がへリカル法 より良かった. またグラフの縦軸を識別可能球体径にすることによ り，容易に装置の限界が理解できた。へリカル法は従来法の分解能 より劣るが, 短時間撮影可能、ボリュームデータを有する, 三次元 構築良好などの点で有用である.ただし臨床ではスライス形状, 病 変の大きさ、CT值差、被曝等を考慮し, 適切な速度、ビーム蝠, mAs值等を設定することが重要である。

\section{CT 2}

\section{座長 福岡大学病院 平田 巧}

\section{3DCT画像最適化の試み一再構築領域 ・関数についてー} 九州大学医学部附属病院 千住竜之

3DCT画像は再構成間隔，領域，関数や補間法など様々な要因の 影隌を受ける．今回は再構成領域および関数について検討を行っ た。アクリルビーズと空気または寒天を用いた自作のファントムお よび臨床例を用い，CT装置で生データからの画像再構成時およひ ワークステーションでのボリュームデータ作成時に拡大したものと の3D画像を比較した。また、画像再構成時、関数を变化させ，そ のときの3D画像も比較を行った．さらに画像再構成時およびボリ ュームデータ作成時にスムージングをかけたものも比較を行った. 画像再構成時に拡大を行うと，輪郭や細部の画質向上がある. 再構 成関数は形状再現性の面からも，エッジ強調の少ない関数を用いる のがよい．スムージングは画像再構成時にかけたものは低コントラ ストのものには有用である.

\section{5 頭部血管CT-Aにおけるサブトラクション法の一考察} 沖縄県立中部病院 染谷明良，他 3 名

【目的】頭部血管3D CT-Aの有用性は、種々報告されている。また， 頭蓋底部の骨陰影除去としてサブトラクション法も報告されてい る.しかし、サブトラクション法は造影前後 2 回のスキャンをす るため、患者被曝も大きくなる．われわれは造影前のマスク像はテ 一ブル送りを粗くし，造影後はテーブル送りを密にすることで被曝 を軽滅し，その有用性を検討した。

【考察】今回のサブトラクション法は造影前後の 2 回の撮影のうち

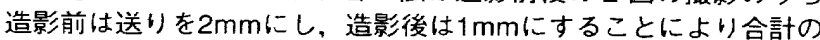
スライス数を減らし，被曝や管球負荷の低隇を目的にしたが、ほぼ 満足な結果を得た。しかし，問題点も多い、頭蓋底部の完全な骨陰 影除去を目標としたが骨陰影が残った場合は，造影前後で患者の動 きによるズレと非同期スキャンであるためと思われる.臨床では， テーブル送り $2 \mathrm{~mm} / \mathrm{s}$ ，スライス幅 $1 \mathrm{~mm}$ を使用し，骨陰影が残っ た場合はスライスを 1 枚ずつ照らし合わせて滅算を行っている.

\section{6 脳動眽㞑診断における3D-CTAの有用性と問題点}

済生会熊本病院 野田由比子, 他 3 名

【目的】䏚動脈瘤の診断における3D-CTAの有用性および問題点を比 較検討した。

【方法】1MRAにて動脈瘤が疑われた124症例を対象に3D-CTAによ る確診率を部位別に検討した。 (2)3D-CTAとIA-DSAを施行した 40 例を対象に動脈瘤の一致率を部位別に評価した. (33D-CTAで動脈
瘤と診断された67例を対象に診断の難易度を部位別に評価した。 【結果】MRAにて動脈瘤が疑われた症例 29.6\%に3D-CTAにおいて も動脈瘤が確認された. 特にACom動脈瘤の検出において3D-CTA の方が有用であった。IA-DSAとほぼ同等の描出能であった。3DCTAプロトコール画像ではACA, VA， BA領域で特に有効であっ た.ICA，MCA領域の検出が比較的困難であった。ICA領域におい ては石灰化や骨が検出の妨げとなった。

【まぬ】3D-CTAは脳動脈瘤診断においていくつかの問題点はある が，有用な検査法と思われる。

\section{7 眼葛内異物CT值の経時的変化による3D-CTの臨床的有用性} 琉球大学医学部附属病院 宮里 毒, 他 5 名

【目的】眼窝内に刺入した木片に対して，位置・形状・大きさ・侵入 方向等確認のためCTを施行. その後，木片の吸收值が経時的に上 昇、3D画像の構案が可能となり臨床上有用となった。その症例と 吸収值の上昇した原因に対し実験を行ったので併せて報告する。 【方法】1)受傷加ら 4 日後に位置・侵入方向等確認のため，13日後 には海綿静脈洞および木片周囲の血管の損傷の有無の確認のため, それぞれCTを施行. 2)木片を生理食塩水および血液中に浸し，吸 収值の経時的変化を観察.

【結果】1)4 日後に施行されたCTにおいて木片は低吸収な像として 描出，13日後には木片は中心に若干低吸収域を残し辺縁から高吸収 化しているのが確認された．2)木片は両者ともに辺縁から高吸収化 し、かつ吸収範围も释時的に顕著に現れていくのが確認された。

治意 1

\section{座長 佐賀医科大学附属病院 廣木昭則}

\section{CTを用いた放射線治療計画の線量評価}

産業医科大学病院 安井修己，他 2 名

【目的】CT画像を使用した放射線治療計画において，CTの撮像条件 や放射線治療計画装置の線量計算マトリクスを変化させた時の、線 量分布に及ほす影䇾について検討を行った。

【方法・結果】Mix-DPファントムと $5 \mathrm{~cm}$ 厚のアクリル板を挟んだ Mix-DPファントムを，スライス厚，FOVを変えてCTスキャン し、線量分布を描かせたが、ともに有為な差はみられなかった。次 に線量計算マトリクスを変化させた時の線量分布を比較したが，ピ 一ク線までの表面近傍と照射野辺縁でその形状に差が出た。また， 同じ幾何学的条件で実測を行い，照射野中心軸での線量を評価した が，計算值との間に大きな差はなく $1 \%$ 以内であった。

\section{9 トンネル型電子線遍敝板を利用した体幹部電子線照射法の 検討}

宮崎医科大学附属病院川村慎二, 他 2 名

成人T細胞白血病や菌状息肉症等びまん性皮唐疾患において，し ばしば広範な治療領域が要求される．SSDを大きくとり，トンネ ル型の電子線遮蔽板を使う広範領域照射法について検討した。結果 として(1)SSD $160 \mathrm{~cm}$ で照射軸を $58 \mathrm{~cm}$ 変位させた 2 門照射によ

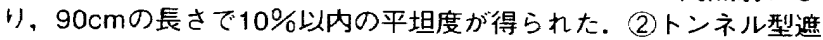
蔽板により体に接することなく，99\%の線量をカットする効果が 得られた. (3)電子線アプリケータをはずした場合，X線コンタミネ ーションの上昇が認められた。(4)体軸垂直方向の照射については， 60 度ごとの 6 門，90度ごとの 4 門照射とも体側部付近で吸収線 量の上昇が認められた。

\section{治事 2}

\section{座長 長畸大学医学部附属病院 後藤紳一}

\section{0 血によるGVHD予防のための血液に対する放射線照射の} 照射楾量と線量分布の確認

久留米大学病院 小野博志

【目的】医療用高エネルギー放射線治療装置による血液バックの隙間 と線量分布との関係を測定し、GVHD予防対策としての放射線照 射方法を検討した。

【方法】1JARP形線量計を使用して，フィルム法による黒化度と線 量の関係を求め, 次にTLD素子およびシャローチェンバの值を校正 した. (2)照射野サイズと第一アクリル層と第二アクリル層の間の空気 層の隙間を変化させて深部吸収線量を測定した。(3)第一アクリル層 と第二アクリル層の間の空気層の除間を一定にし，照射野サイズを変 化させて，第二アクリル層表面と基準点の線量を測定し比を求めた。 【まぬ】一方向照射で，最下部に目的線量を入射した場合の，血液 パックの隙間が吸収線量に与える影響の検討では，(1照射野サイズ 